\title{
Current Management Options in Caesarean Scar Ectopic Pregnancy- Mini Review
}

Asiri $\mathbf{M}^{*}$

King Saud Medical City Maternity Hospital, Saudi Arabia

*Corresponding author: Mufareh Asiri, Maternity Hospital, King Saud Medical, Riyadh, Saudi Arabia, Email: dr.mufareh@yahoo.com

\section{Mini Review}

Volume 6 Issue 1

Received Date: January 11, 2021

Published Date: January 25, 2021

DOI: $10.23880 /$ oajg-16000208

\section{Mini Review}

Caesarean scar ectopic pregnancy is defined as a gestational sac that implants into the scar site from a previous caesarean delivery [1].

The long-term risks of caesarean delivery are subsequent ectopic pregnancies, uterine rupture, and placental disorders in future pregnancies such as abruptio placentae, placenta previa, and placenta accreta, which is the most serious condition $[2,3]$.

The literature suggests that caesarean delivery scar pregnancy is increasing in the incidence than before. Its incidence ranges from 1:1,800 to 1:2,216 pregnancies, and it represent $6.1 \%$ of all ectopic pregnancies with a history of one caesarean delivery at least $[4,5]$.

The diagnosis of scar ectopic pregnancy is so challenging as the patient presentations vary considerably, with one third of patients remaining asymptomatic at time of diagnosis [1]. Because of this unspecific presentation, about $10 \%$ of scar ectopic cases are misdiagnosed [6].

Most of the cases are asymptomatic, other could present with painless vaginal bleeding, or generalized abdominal pain [1]. The diagnostic criteria for scar ectopic pregnancy include a positive pregnancy test, transvaginal ultrasound that demonstrates an empty uterus and cervical canal, a gestational sac at the scar site, thin or absent myometrial tissue between the bladder and the gestational sac, and a vascular area noted at the previous caesarean scar [7].

There are two types of scar ectopic pregnancy have been described. First one is (endogenic) where the gestational sac grows inward toward the cervico-isthmus space, whereas the second one is (exogenic) where the gestational sac grows outward toward the bladder and abdominal wall. More than 30 different treatment options for scar ectopic pregnancy have been reported [8].

Several treatment modalities have been utilized to treat scar ectopic pregnancy. These can be categorized as expectant, medical, UAE, surgical, and combination [9]. Expectant management has been chosen as an option when a patient wants this after counselling with respect to the outcome of the pregnancy. This option has a high morbidity rate and should be undertaken only with stable patients [10].

Overall, the expectant management results in poor outcomes, and it should not be recommended as first-line treatment in most individuals with scar ectopic pregnancy [9]. Medical management can be used with systemic (intramuscular) medications or local (intra-gestational). Methotrexate (MTX) is mostly used, as obstetricians and gynaecologists have the most experience with this medication in the treatment of ectopic pregnancy. Other medical options have been used, like potassium chloride, gefitinib, ethanol, hyperosmolar glucose, vasopressin, mifepristone, and crystalline trichosanthin; unfortunately, limited data is available regarding their use [11-13].

Uterine artery embolization has a various reported range of success and complication rates, and it has been suggested that UAE should be used only in those with arteriovenous malformations or when there is considerable bleeding [14].

Many surgical methods have been described to treat patients with scar ectopic pregnancy including D\&C; excision of scar ectopic pregnancy via abdominal, laparoscopic, hysteroscopic, or vaginal approach; a combination approach; but definitive management is through hysterectomy. 


\section{Open Access Journal of Gynecology}

\section{Conclusion}

Scar ectopic pregnancy remain one of the difficult and debate topic due to unspecific presentation and the treatment is individualized based on patient's condition, location of the pregnancy, desire for future fertility and surgeon preference based on his experience and available facilities.

\section{References}

1. Rotas MA, Haberman S, Levgur M (2006) Cesarean scar ectopic pregnancies: etiology, diagnosis, and management. Obstet Gynecol 107(6): 1373-1381.

2. Hemminki E, Merilainen J (1996) Long-term effects of cesarean sections: ectopic pregnancies and placental problems. Am J Obstet Gynecol 174(5): 1569-1574.

3. Chazotte C, Cohen WR (1990) Catastrophic complications of previous cesarean section. Am J Obstet Gynecol 163(3): 738-742.

4. Jurkovic D, Hillaby K, Woelfer B, Lawrence A, Salim R, et al. (2003) First trimester diagnosis and management of pregnancies implanted into the lower uterine segment cesarean section scar. Ultrasound Obstet Gynecol 21(3): 220-227.

5. Seow KM, Huang LW, Lin YH, Lin MY, Tsai YL, et al. (2004) Cesarean scar pregnancy: issues in management. Ultrasound Obstet Gynecol 23(3): 247-253.

6. Gonzalez N, Tulandi T (2017) Cesarean scar pregnancy: a systematic review. J Minim Invasive Gynecol 24(5): 731-738.

7. Timor-Tritsch IE, Monteagudo A, Santos R, Tsymbal T,
Pineda G, et al. (2012) The diagnosis, treatment, and follow-up of cesarean scar pregnancy. Am J Obstet Gynecol 207(1): 44.e1-44.e13.

8. Birch Petersen K, Hoffmann E, Rifbjerg Larsen C, Nielsen HS (2016) Cesarean scar pregnancy: a systematic review of treatment studies. Fertil Steril 105(4): 958-967.

9. Glenn TL, Bembry J, Findley AD, Yaklic JL, Bhagavath B, et al. (2018) Cesarean Scar Ectopic Pregnancy: Current Management Strategies. Obstet Gynecol Surv 73(5): 293-302.

10. Liu H, Leng J, Shi H, Lang J (2010) Expectant treatment of cesarean scar pregnancy: two case reports and a glimpse at the natural courses. Arch Gynecol Obstet 282(4): 455458.

11. Kanat-Pektas M, Bodur S, Dundar O, Bakır VL (2016) Systematic review: what is the best first-line approach for cesarean section ectopic pregnancy? Taiwan J Obstet Gynecol 55(2): 263-269.

12. Maheux-Lacroix S, Li F, Bujold E, Nesbitt-Hawes E, Deans $\mathrm{R}$, et al. (2017) Cesarean scar pregnancies: a systematic review of treatment options. J Minim Invasive Gynecol 24(6): 915-925.

13. Mollo A, Conforti A, Alviggi C, De Placido G (2014) Successful direct bipolar resection of 6 th week cesarean scar pregnancy: case report and literature review. Eur J Obstet Gynecol Reprod Biol 179: 229-231.

14. Sadeghi H, Rutherford T, Rackow BW, Campbell KH, Duzyj CM, et al. (2010) Cesarean scar ectopic pregnancy: case series and review of the literature. Am J Perinatol 27(2): 111-120. 